\title{
CONSIDERATIONS REGARDING THE EVOLUTIONS OF ATMOSPHERIC PRECIPITATIONS IN THE SPRING SEASONS IN IAȘI AREA - CASE STUDY: THE METEOROLOGICAL EVENT DATED ON 14 APRIL 2016
}

\author{
Ovidiu - Miron Machidon ${ }^{1}$, Diana - Corina Bostan ${ }^{1}$
}

Key words: abundant precipitation, flood, spring, trends, Iaşi

\begin{abstract}
The study is a comparative analysis of the characteristics of atmospheric precipitations in spring seasons from the WMO reference periods (1961 - 1990, 1981 - 2010) compared with last 7 years $(2010$ - 2016). In 14 april 2016 a meteorological event was produced in the Iași area who have produced material damage, flooded streets and obstruction of traffic. In the spring seasons of the last 7 years (2010-2016) the atmospheric precipitation amounts were with $8 \%$ higher than during $1981-2010$ and were apropiate on mean value of the $1961-1990$. In the period of 1961 - 2016 were a continuous increase of the mean number of days with precipitation $>30 \mathrm{~mm}$ per day and the half of total number of days with more than $40 \mathrm{~mm}$ per day were recorded in the last 16 years. We consider that an increase of torrential character of precipitation in the spring season in Iași area.
\end{abstract}

\section{Introduction}

In the first decade of the 21st century, the territory of Moldavia has faced with unprecedented sequence of very warm periods and very moist and rainy periods, some of them surpassing the records of the entire period of meteorological observations.

The National Meteorological Administration in Romania has recently conducted an assessment of the current climate in Romania, featuring the atmospheric precipitations, mainly in terms of its territorial distribution and secondly regarding its time evolution (Climate of Romania, 2008). For the different parts of the Moldavia, different analyses of the atmospheric precipitations was

\footnotetext{
${ }^{1}$ Regional Meteorological Centre of Moldova, National Meteorological Administration of Romania, E-mail: ovidiumachidon@yahoo.com,dianabostan@yahoo.com
} 
made (Precupanu-Larion, 1999; Bradu, 2004; Mihăilă, 2006; Bostan at all, 2009, Mihăilă at all, 2008, 2009).

The recent climatic studies showed a slight downward trend of atmospheric precipitations from the period of 1961 - 2007 in the Iași area (Busuioc at all, 2010), or an increasing trend if we take into account the period of $1945-2010$ (Machidon, 2011). Some other studies have analyzed the variations of precipitations (Dragotă, 2006; Tănase, 2010), or the impact of climatic teleconnections identified in the Northern Hemisphere on precipitations variability from Moldova territory (Sfica L, 2004).

\section{Methodology}

The paper is based primarily on the factual material represented by continually measured data of atmospheric precipitations during the spring seasons between 1961 and 2016 at the meteorological station located in Iași (fig. 1).

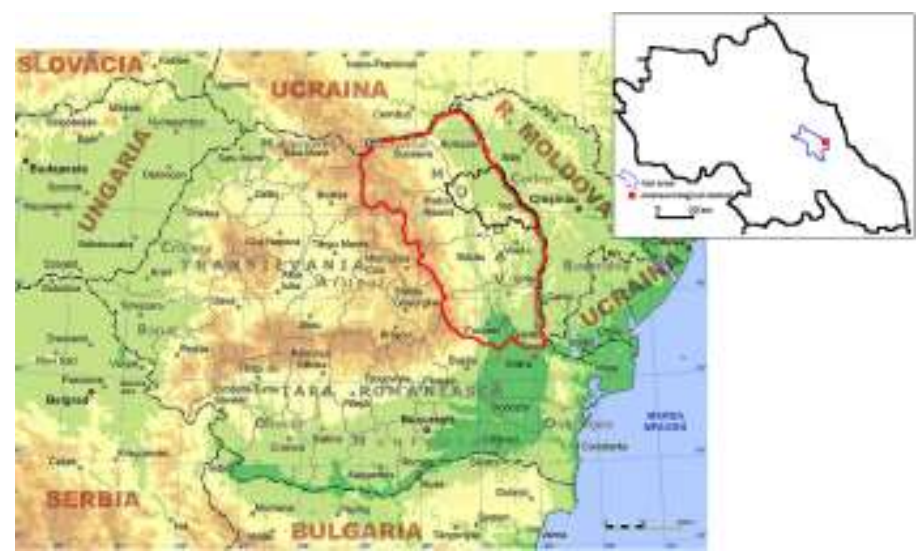

Fig. 1. Location of meteorological station in Iaşi area

The WMO reference periods (1961-1990; 1981-2010) compared with last 7 years, the statistical-mathematical processing of the climatic data and their graphical representation are the methods through which the corpus of data collected from the weather stations measurements has been developed. Furthermore, both methods were used in the graphical transposition of the results obtained by averaging the data from the Iași meteorological station. In order to establish a trend, we have used the method of moving averages, on a time series of 10 years, shifted with a year calculated by averaging the values recorded by weather station. The trend line has been drawn by using EXCEL.

In the study case were used the satellite images, synoptic maps, photos and the images obtained with the Doppler weather radar from Bârnova, Iaşi county. 


\section{Obtained results}

Climatic analysis. Long-term trends, in 1961-2016 period, of the atmospheric precipitation evolution in the spring season, show the rising trend in the last 15 years in Moldova region (fig. 2). One can readily observe that, the periodic evolution of mean values of precipitation quantities in the spring, throughout the WMO reference periods, indicates a decreasing trend from 1961- 1990 period to 1981- 2010 period, but a rising trend in the last 7 years (fig. 3).

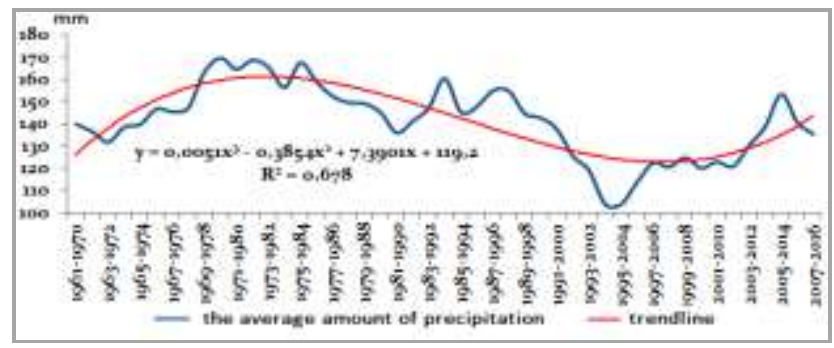

Fig. 2. The moving averages over a 10-year time series, shifted successively with one year of the average precipitation amounts in the spring at Iași meteorological station $(1961-2016)$

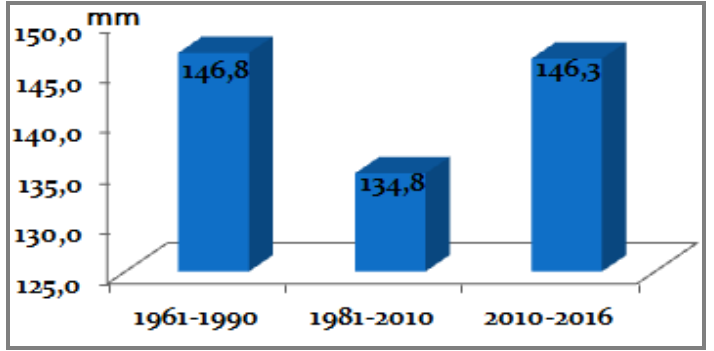

Fig. 3. Periodically mean amounts of the atmospheric precipitation quantities in the spring at Iași meteorological station from the periods of $1961-1990$, $1981-2010$ and 2010-2016

The number of days with rain has periodically decreased in spring (fig. 4). At the same time it is noted that the shower days has excessively increased from period to period (fig. 4). That indicates the fact that convective phenomenon has increased in the sping season in the area of Iasii.

The study of the frequency of maximum amount of precipitation in 24 hours and their proportion from the total monthly quantities it gives an idea of the negative potential which significant rains may have on economic and social activity from a certain region. 
The periodic evolution of the number of days with precipitation of $\geq 0.1 \mathrm{~mm}$ (Fig. 5), throughout the WMO reference periods and last 7 years, indicates a decreasing trend. The mean number of days with precipitation $\geq 30 \mathrm{~mm}$ indicates a shift of the deviations towards the register of values above average, this being an argument in favour of increasing of the torrential character of precipitation in spring, more pronounced in the last 7 years (Fig. 5).

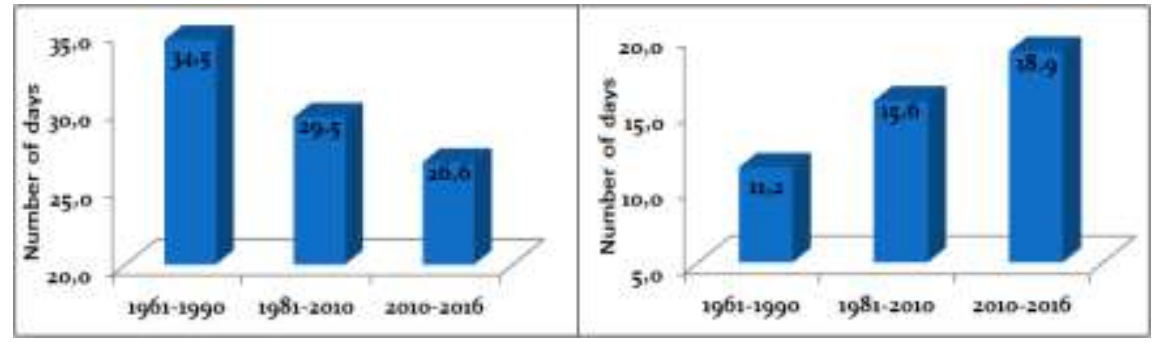

Fig. 4. Periodically number of days with rain and number of shower days in the spring season at Iași meteorological station from the periods of $1961-1990,1981-2010$ and 2010-2016

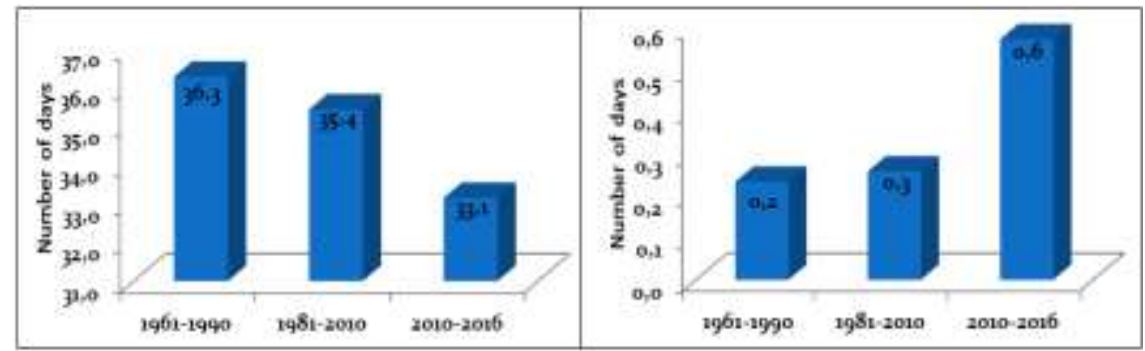

Fig. 5. Periodically number of days with precipitation $\geq 0,1 \mathrm{~mm}$ and $\geq 30 \mathrm{~mm}$ per day in the spring season at Iași meteorological station from the periods of 1961 - 1990, $1981-2010$ and 2010-2016

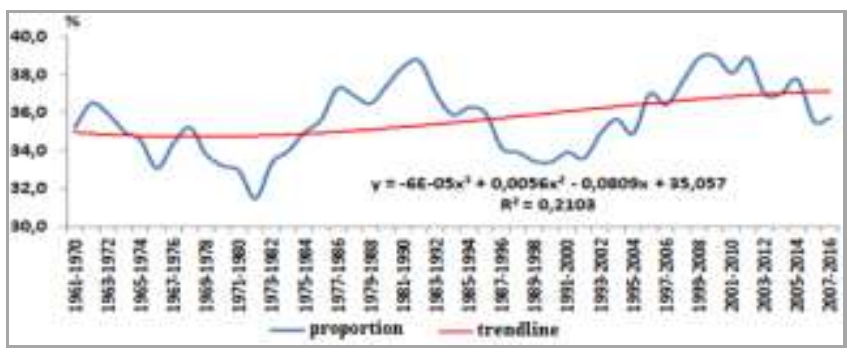

Fig. 6. The evolution of the proportion of maximum quantities of rainfall in 24 hours from the total monthly quantities in the spring seasons at Iași meteorological station 
The evolution of the proportion of maximum quantities of rainfall in 24 hours from the total monthly quantities shows a slightly upward trend in the spring (Fig. 6). The percentage values from the total monthly precipitation quantities increase with the maximum quantity of precipitations in 24 hours (Fig. 7). 50\% of all cases within maximum quantity $\geq 40 \mathrm{~mm}$ in 24 hours were produced during the period 2000-2016.

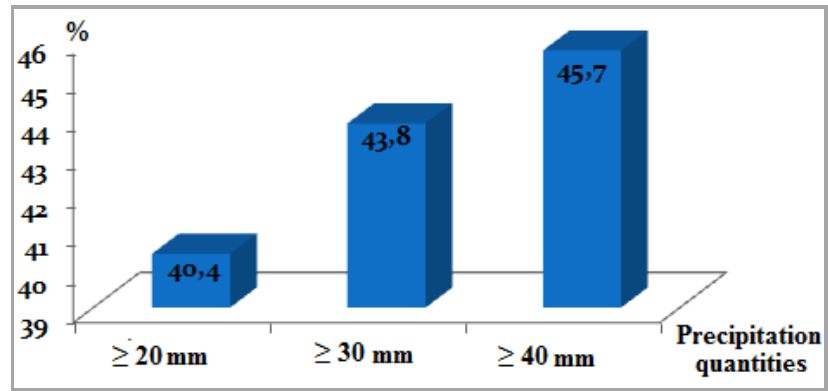

Fig. 7. The mean proportion of maximum quantities of rainfall in 24 hours (on various thresholds) from the total monthly quantities in the spring seasons at Iași meteorological station (1961-2016)

Study case: Analysis of meteorological event produced in Iași area on 14 April 2016 At ground level in 14 April 2016, 12 and 18 UTC, the synoptic situation is the one on the synoptic map presented in fig. 8. Northeastern Romania was under a low pressure area which occupies most of the Eastern European continent.

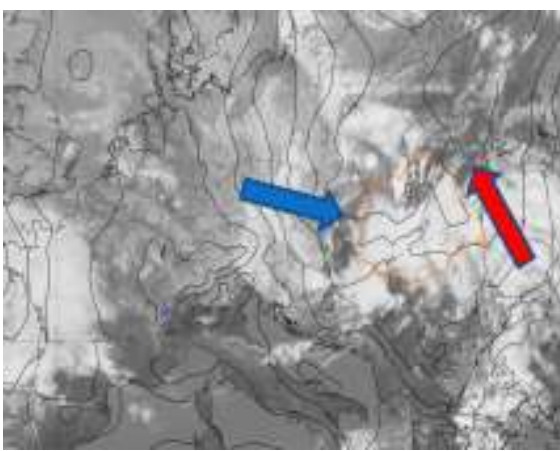

12 UTC

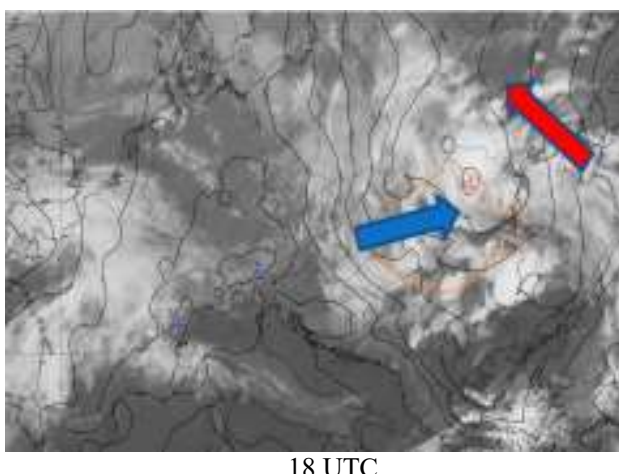

18 UTC

Cold air mass direction

Warm air mass direction

Fig. 8. Synoptic situation on 14 April 2016, 12 and 18 UTC at ground level (source: http://eumetrain.org/eport.html) 
In the temperature land al the level $850 \mathrm{~h} \mathrm{~Pa}$, our country was under the influence of an air mass of polar maritime origin, the whole territory of Moldavia being situated between $8-11^{\circ} \mathrm{C}$ (fig 9).

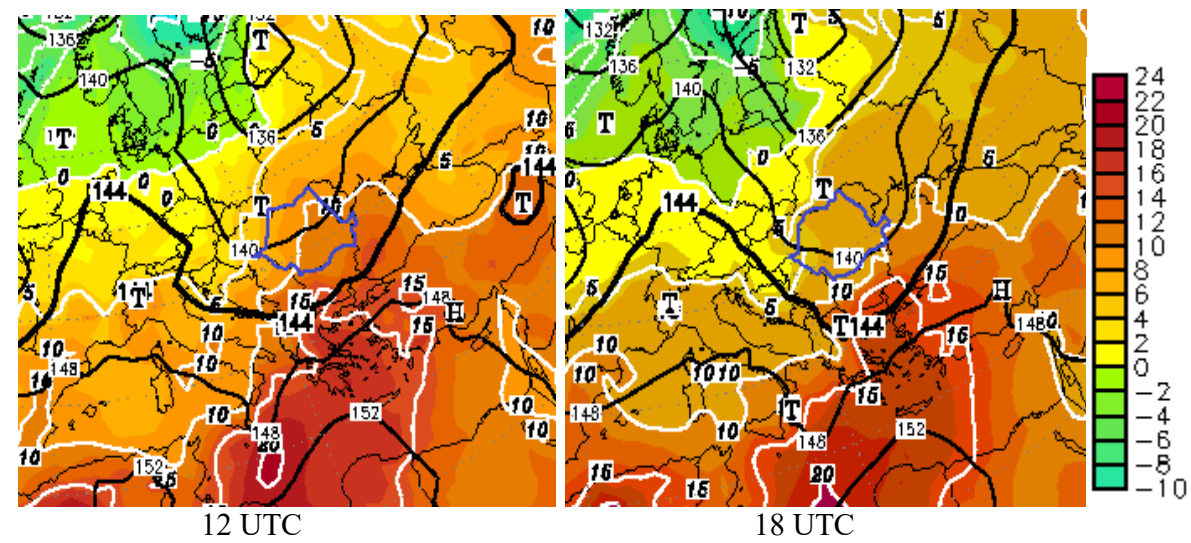

Fig. 9. The geopotential (gpdam) and surface-level air isobaric temperature $\left({ }^{\circ} \mathrm{C}\right)$ of $850 \mathrm{hPa}$ on April, 2016 at 12 and 18 UTC (source: www.wetter3.de)

CAPE provides a good measure of the degree of instability, representing the amount of potential energy for a high particle at the level of neutral buoyancy. This item depends on the initial conditions of the particle and of the thermo-dynamic procedures used to raise the particle, the unit of measurement being $\mathrm{J} / \mathrm{kg}$ (Jouli per kilogram). Abundant rainfall during the day of April 14, 2016 had front causes (fig. 8 ) accompanied by the instability level during the afternoon (fig. 10).

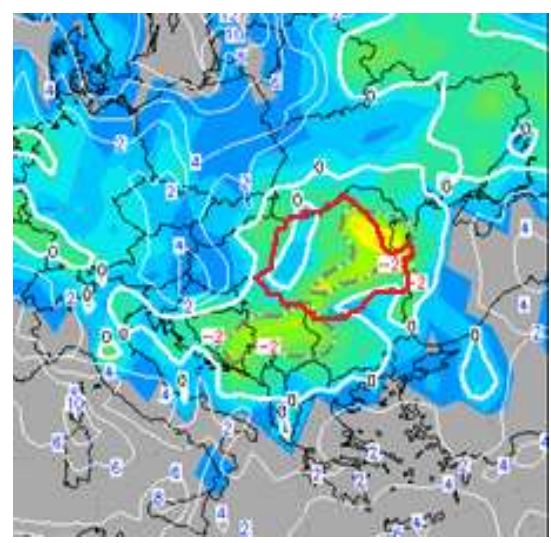

12 UTC

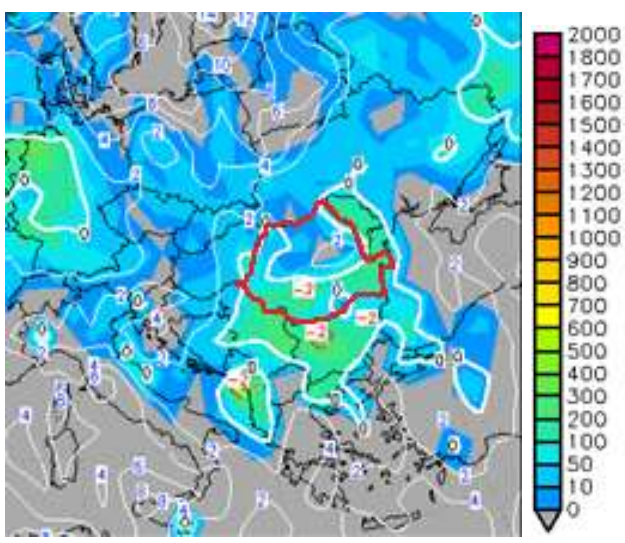

18 UTC

Fig. 10. Lifted Index (K) mixed layer Convective Available Potential Energy (CAPE) on 14 April 2016, 12 and 18 UTC (source: www.wetter3.de) 
At the evening of April 14, 2016 had been met conditions of occurrence of severe convective phenomena due both to cold frontal passage and thermal convection. In their evolution, convective phenomena have reached the area of Iasi municipality after 15.30 UTC (tab. 1). These have been happened and were captured by satellite images (fig. 8) and radar products (fig. $11-15$ ).

Tab. 1. Weather phenomena recorded on 14 April 2016 at Iasi meteorological station

\begin{tabular}{||c||c|c||}
\hline $\begin{array}{c}\text { Meteorological } \\
\text { station }\end{array}$ & $\begin{array}{c}\text { Altitude } \\
(\boldsymbol{m})\end{array}$ & \multicolumn{1}{|c|}{$\begin{array}{c}\text { Weather phenomena } \\
\text { (occurrence time-UTC) }\end{array}$} \\
\hline \hline \multirow{2}{*}{ Iași } & 104 & $\begin{array}{l}\text { Dew (00.00-08.55); Lightning (15.02-18.45); Showers } \\
(15.55-18.41,18.58-19.26,19.58-21.10,23.40-23.56), \\
\text { Hail (16.18-16.26) }\end{array}$ \\
\hline
\end{tabular}

The height of the clouds in the area of Iași municipality was varied between 3 and $9 \mathrm{~km}$. In the vicinity of Iasi, in the northwestern extremity, the height ranged between 9 and $12 \mathrm{~km}$ (Fig. 11).
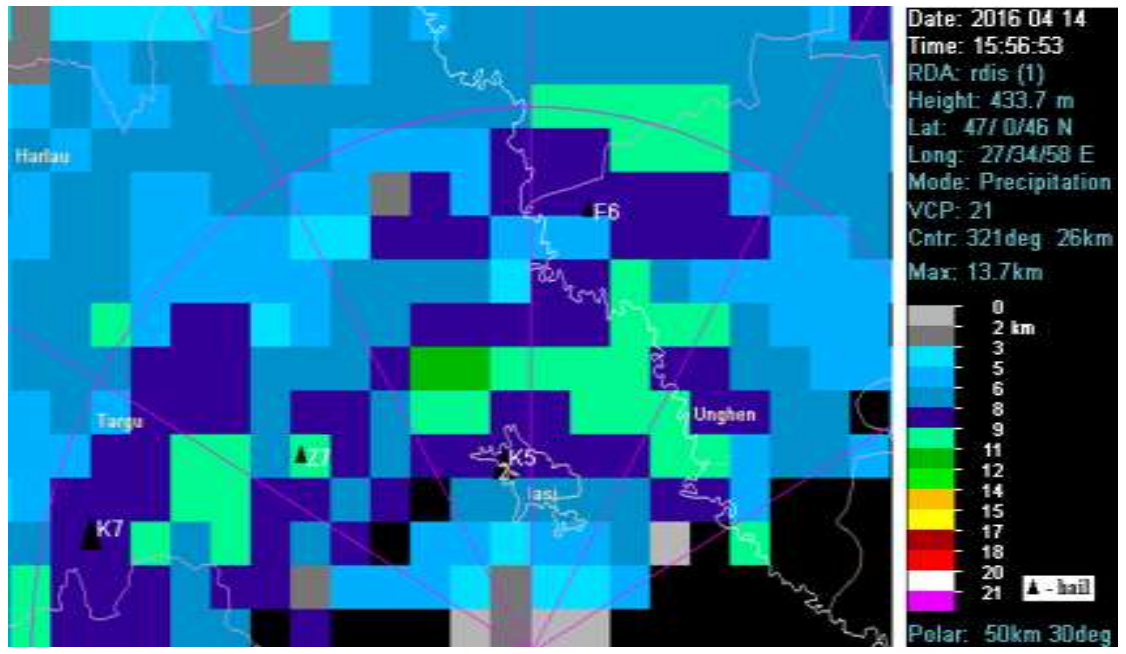

Fig. 11. Locations with hail and height of clouds estimated by Doppler radar from Bârnova, Iaşi county

Convective clouds were characterized by a maximum values of reflectivity that have reached $65-70 \mathrm{DBZ}$ (fig. 12). The probability of hail was by $100 \%$.

The OHP product of the Doppler radar, which estimate the amount of precipitation by the different periods of time, indicate the fact that the high intensity of rainfall was between 15.30 to $16.30 \mathrm{UTC}$, in the central and northwest 
part of Iași, where the Doppler radar estimated maximum quantities of precipitation between 30 and $60 \mathrm{~mm} / 1$ per hour (fig. 13).

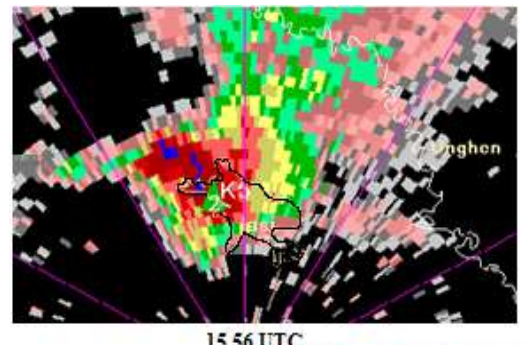

15.56 UTC

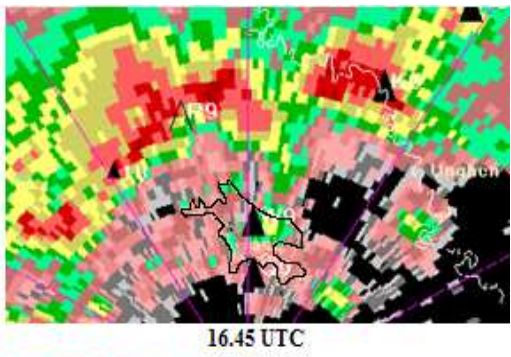

16.45 UTC

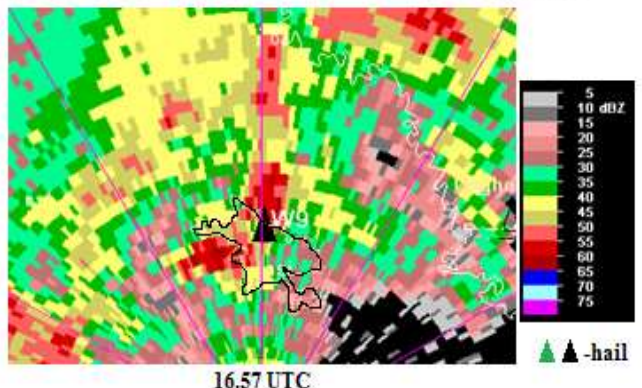

Fig. 12. Radar reflectivity and locations where have occurred hail
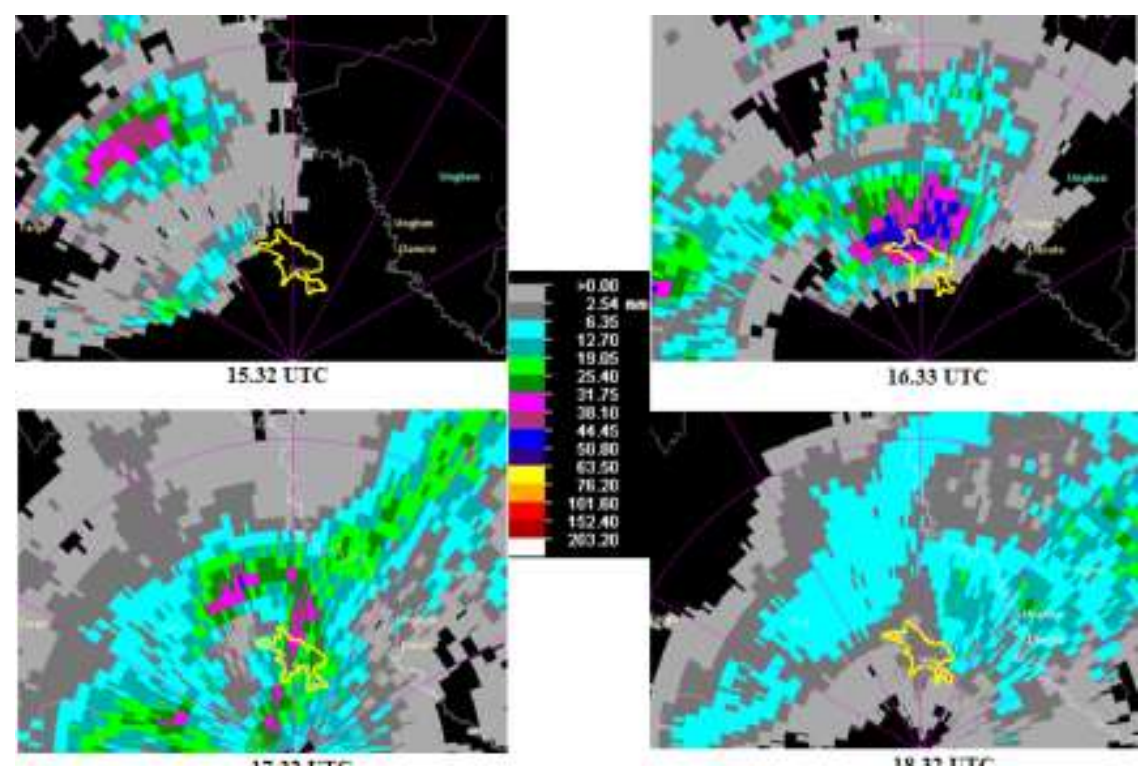

17.32 tTC

18.32 UTC

Fig. 13. Estimation of precipitation quantities during 1 hour with Doppler radar located at Bârnova, Iaşi county 
In the area of Iasi, the precipitation quantities estimated per 24 hours by Doppler radar have indicated maximum values between 13 and $100 \mathrm{~mm}$ (fig. 14). In the same figure it can be observed that the precipitation measured in locations positioned at the soil surface confirms the values which was estimated by Doppler radar.

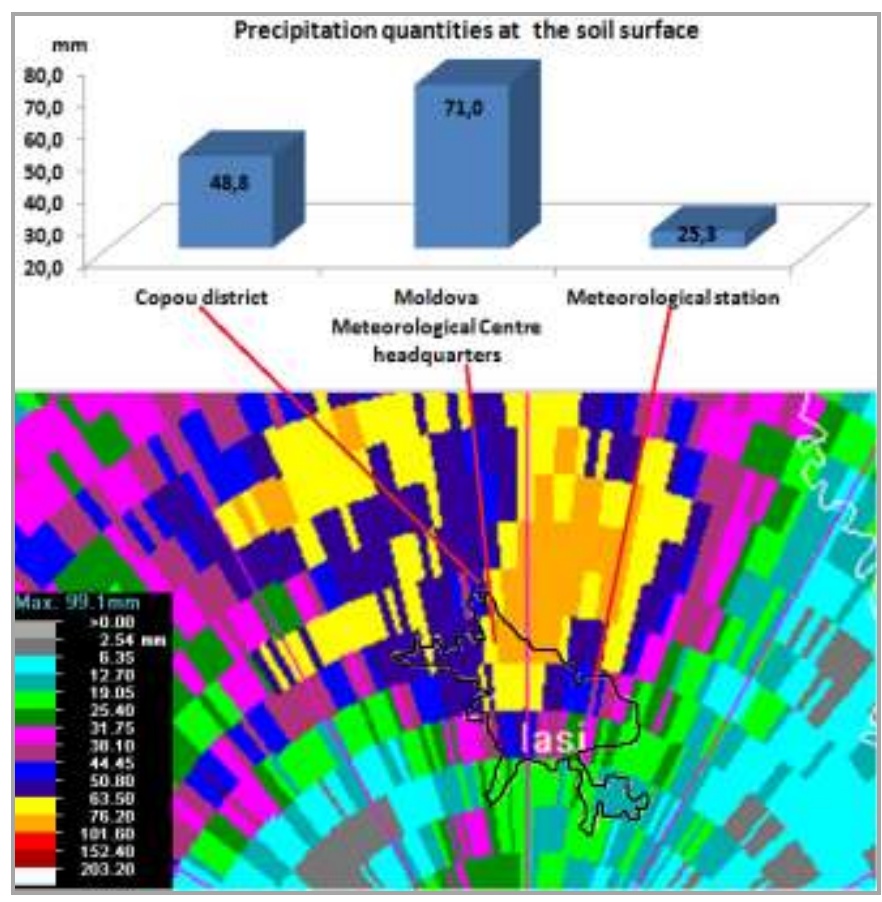

Fig. 14. Precipitation quantities - estimation during 24 hour (13.04.2016, 20.00 UTC - 14.04.2016, 20.00 UTC) with Doppler radar and precipitation data measured at soil surface

Efects:

The meteorological event produced in the Iași at 14 april 2016 have generated material damage, flooded streets and obstruction of traffic (fig. 15).

Regies, companies and directions subordinated to the municipal authorities have had interventions during the all night. The the next areas from Iași had been most affected by the weather: Alexandru cel Bun - Dacia - Sarmisegetuza, Podul de Piatră - Ipsilanti street, Păcurari - Toma Cozma street, embankment of Bahlui River - left bank of the river (fig. 16), Nicolae Iorga boulevard-including Galata passage, the passage placed at the end of Păcurari district.

Due to heavy rains, the administration representatives of local public transport were forced to replace trams on routes 3,13 and 1 by buses. The County 
Inspectorate for Emergency Situations were called in 13 cases to remove water from yards and homes, according to statements in local media.
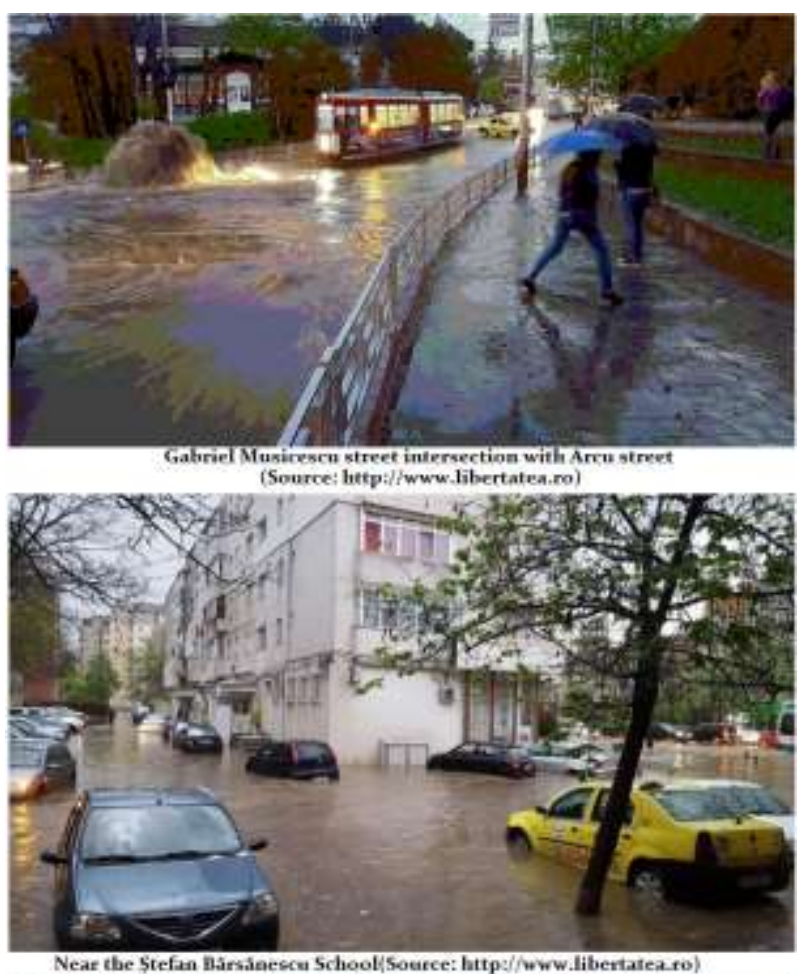

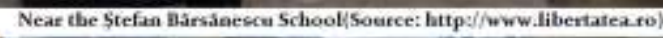

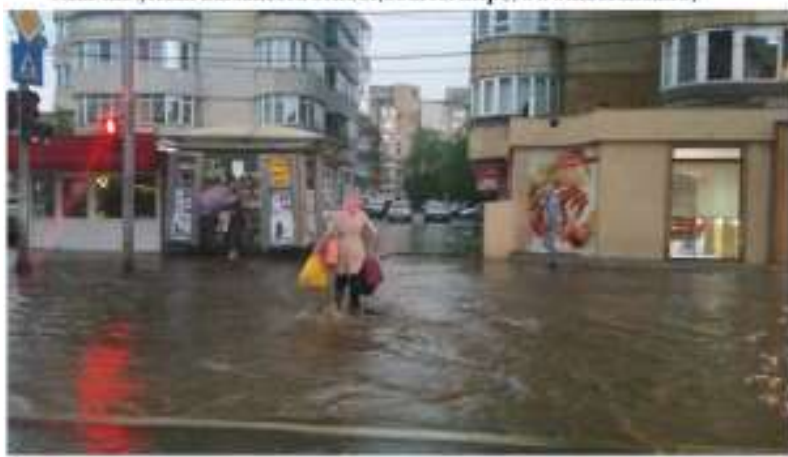

Strappungerea Silvestru street iatersection with Bacinschi street

ource: httpol/www Hibertatea.co

Fig. 15. Photo images of the effects of rainfall from April 14, 2016 in the area of Iasi 

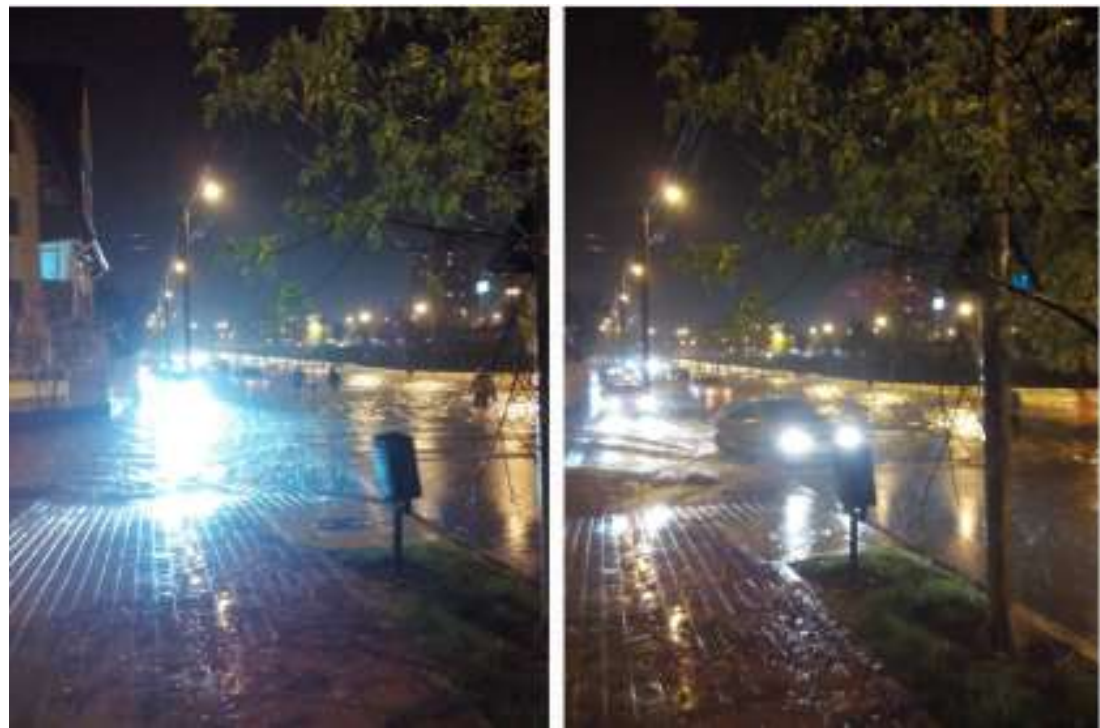

Fig. 16. Photo images of the effects of rainfall from April 14, 2016 in the area of embankment of Bahlui River - left bank of the river (Source: Petronela Cotea Mihai)

\section{Conclusions}

In the last 7 years (2010-2016), in the spring seasons, the mean quantities of atmospheric precipitations has decreased by $7 \%$ from $1961-1990$, but were $1 \%$ higher than the period 1981-2010.

The number of days with precipitation of $\geq 0.1 \mathrm{~mm}$ is declining, the average value for the last 7 years being the $13 \%$ smaller than the average value of the 1961 1990 period, respectively $11 \%$ compared to the $1981-2010$ period.

The number of days with precipitation of $\geq 30 \mathrm{~mm}$ it tripled in the period 2010 -2016 (the last 7 years) compared to the 1961-1990 period and doubled against the 1981-2010 period.

These characteristics are clear arguments that the torrential character of atmospheric precipitations was intensified in the spring seasons in the area of Iași and the case study reinforces the assertion made out.

\section{References}

Apostol, L. (2004). Clima Subcarpaților Moldovei, Editura Univ. Suceava, ISBN 9739408-81-8, Suceava. 
Bostan, D., Mihăilă, D., Tănasă, I. (2009), The abundant precipitation in the period 22nd-27th of July, 2008 from Suceava county and the surrounding areas. Causes and Consequences, Revista „Riscuri si catastrofe”, vol. VIII, nr. 6, Editura Casa Cartii de Știință, Cluj Napoca;

Bradu, T. (2004), Clima Colinelor Tutovei, Teza de doctorat, Facultatea de Geografie Geologie, Univ. „Al. I. Cuza”, Iaşi;

Busuioc, Aristița, Caian, Mihaela, Cheval, S., Bojariu, Roxana, Boroneanț, Constanța, Baciu, Mădălina \& Dumitrescu, A. (2010), Variabilatea și schimbarea climei în România, Editura Pro Universitaria, ISBN 978-973-129-549-7, București;

Dragotă, Carmen (2006), Precipitațiile excedentare in România, Ed. Academiei Romane, ISBN 973-27-1435-2, București;

Machidon, O. \& Machidon, Dana (2011), Study of the evolution of atmospheric precipitation in Moldavia region (Romania) over the last 65 years, Annals of DAAAM for 2011 \& Proceedings of 22nd International DAAAM Symposium, ISBN 978-3-901509-83-4, ISSN 1726-9679, pp 1523-1524, Editor Branko Katalinic, Published by DAAAM International, Vienna, Austria;

Machidon, O., Apostol, L., Buruiană, D, Machidon, Dana, (2012), Study of the Evolution of Air Temperature in Moldavia Region (Romania) Over the Last 65 Years, Annals of DAAAM for 2012 \& Proceedings of the 23rd International DAAAM Symposium, ISBN 978-3-901509-91-9, ISSN 2304-1382, pp 0689 - 0692, Editor $\mathrm{B}[\mathrm{ranko}]$ Katalinic, Published by DAAAM International, Vienna, Austria;

Mihăilă, D. (2006). Câmpia Moldovei - studiu climatic, Ed. Univ. Suceava, ISBN 973666-219-5, Suceava;

Mihăilă, D., Tănasă, I., Bostan D., (2008)- The Precipitations from the Evening of June 30, 2006 from Arbore; Causes and Consequences, Lucrările Seminarului Geografic „Dimitrie Cantemir”, Nr. 28, pp. 73 - 83;

Mihăilă, D., Bostan D., Tănasă, I., (2009), Les precipitations abondantes de l'ouest d' Ucraine et du nord de Moldavie, enregistrées dans la période 23-28 juillet 2008. Causes et consequences, Geographia Technica, Vol. 04, Special Issue, pp. 317-322;

Precupanu-Larion, D. (1999), Clima municipiului Vaslui, Teza de doctorat, Fac. de Geografie-Geologie, Univ. “Al. I. Cuza”, Iaşi

Sfică, L., (2004), L'impact des téléconnexions climatiques dans la variabilité des quantités de précipitations dans la région de la Moldavie, Analele Universității "Ovidius" seria Geografie, nr. 2, vol. I, 2004.

Tănase, I. (2010), Clima Podişului Sucevei - fenomene de risc, implicaţii asupra dezvoltării durabile, Teza de doctorat, Univ. Stefan cel Mare, Suceava;

***(2008), Clima României, Ed. Academiei Romane, ISBN 978-973-27-1674-8, Administrația Națională de Meteorologie din România, București;

***(1961-2016), Meteorological Tables TM1-1M, from the archive of Regional Meteorological Centre of Moldova (Romania), Iași

*** www.wetter3.de

*** http://eumetrain.org/eport.html

*** http://www.libertatea.ro

*** http://www.ziare.com/ziare-iasi/stiri-actualitate/prapad-dupa-potop-6075486 